\title{
CONSEQUENCES OF COMPLIANCE AND DETERRENCE MODELS OF LAW ENFORCEMENT FOR THE EXERCISE OF POLICE DISCRETION
}

\author{
Albert J. Reiss, Jr.*
}

\section{INTRODUCTION}

The modern police originally coalesced diverse law enforcement functions into a single organization. In the United States of the 1830's these functions included the major crime control functions of the watch, including maintaining the Sabbath; of the market police whose goals were to detect and apprehend persons in the act of breaking the law; and of the inspectorates who secured compliance with the law by regulating a host of environmental and social situations and exchanges. Bacon calls our attention to the diversity of the inspectors' functions.' There were, for instance, inspectors of chimneys who had the right to enter any domicile to determine whether a chimney was made of wood, inspectors to check for the presence of pigs in the street, and inspectors to oversee the compliance of market commodities, weights, and measures with applicable standards. Among the powers held by inspectors in general were those to license, exact compliance, apprehend, enter private places without prior notice, and serve public notices. It was not uncommon to have several dozen such inspectors in small communities, and over a hundred in larger cities, such as Boston or Philadelphia. Many inspectors, of course, were appointed on a part-time or fee-system basis.

Inspectorial, watch, and constabulary functions were merged to form police departments in the nineteenth century in America. Over time, however, municipal governments separated these functions, with the watch and constabulary functions becoming the task of police patrol and the inspectorial functions transferred to separate departments or agencies of government. ${ }^{2}$

Copyright (ㄷ 1984 by Albert J. Reiss, Jr.

* I am indebted to Abraham Goldstein, Richard O. Lempert, and Lawrence W. Sherman for suggestions on the approach taken in this article. Sherman's important experiments in police practice have helped shape my thinking and understanding of police behavior and practice. The work of Egon Bittner, likewise, has been a fruitful source of rethinking police practice, as this article merges earlier writing on police behavior with my more recent work on the regulation of organizational behavior. The latter work was supported under NIJ Grant \#80-IJ-CV-0106.

1. For a detailed study of the inspectorate in colonial America and the origin of the first police departments in the United States, see generally S. Bacon, The Early Development of American Municipal Police: A Study of the Evolution of Formal Controls in a Changing Society (1939) (unpublished Ph.D. dissertation, Yale University).

2. The inspector continues to be an officer of law rank in many executive agencies that perform 
By the end of the nineteenth century, crime control had emerged as the core function of police departments. The apprehension of criminals and the prevention of crime were delegated to line officers on police patrol. The investigation and solution of criminal matters, leading to the apprehension of criminals, became the work of an elite group within the department-the detectives.

In contrast to police departments of late nineteenth century America, the emphasis of the inspectorate had always been preventive, that of compliance with the law. The objectives of the inspectorate were to protect the public from the unscrupulous, to develop public trust, to facilitate the exchange of commodities, and to promote the general welfare by insuring public safety. The inspectorate's business was not that of filling jails, which were few, but of preventing violations by controlling and ordering relations among people.

The separation of the inspectorate from the watch and constabulary and a shift in the emphasis of police departments to crime control scanted the peacekeeping and order-maintenance functions of policing in important ways. ${ }^{3}$ Gradually, the criminal law, as well as police managers and ultimately the line officers, came to treat peacekeeping and order-maintenance functions as residual matters. The law often came to regard peacekeeping and ordermaintenance functions as matters to be left to the lowest level of municipal code enactment and enforcement. The organizational business of policing, especially in large departments, increasingly emphasized the apprehension of offenders and the discretionary powers of police officers in making arrests and gathering evidence.

The history of the police's power to arrest provides an interesting example

regulatory or law enforcement functions. There are, for example, municipal fire inspectors, health inspectors, safety inspectors, and inspectors of weights and measures. The office of Inspector survives in some major United States police departments, although somewhat anomalously, as an office of a more exalted rank, such as Chief Inspector of Patrol or of Detectives.

3. There is considerable variation in the literature on policing concerning the distinction between keeping the peace and maintaining order and on differentiating both of these from the concept of police service and law enforcement. James $Q$. Wilson, for example, makes no distinction between order maintenance and peacekeeping but differentiates order maintenance from law enforcement. Order maintenance for Wilson consists of the "absence of disorder, and by disorder is meant behavior that either disturbs or threatens to disturb the public peace or that involves face-to-face conflict among two or more persons." J. Wilson, Varieties of Police Behavior 16 (1968). He distinguishes order maintenance from law enforcement since the goal of the latter is to enforce the law rather than to maintain a pattern of public order. Id. Although a distinction that separates peacekeeping from order maintenance functions of police is easily overdrawn, here they are treated as somewhat separable since neither is all-inclusive. The peacekeeping functions of the police are those that deal with disturbance of both public and private social orders. Thus, there is as much concern with settling the family dispute as the tavern dispute. "The respect for private ordering that is formal in civil law is informal in criminal law." Reiss \& Bordua, Environment and Organization: A Perspective on the Police, in The Police: Six Sociological Essays 1, 30-31 (A. Bordua ed. 1967). Order maintenance includes not only the maintenance of private order and prevention of disorder, whether that of the private dispute or the mob in riot, but the maintenance of fundamental ordering of public activity in daily life as well. The prevention of gridlock, the warning of potential dangers to safety, and the maintenance of the orderly flow of traffic are important features of order maintenance in modern society, and such functions are generally delegated to the public police. These policing functions are to be distinguished from more specific police services such as completing auto accident reports, assisting persons in distress, and dealing with lost persons or property. 
of this shift in emphasis. Initially, the power of police officers to arrest on their own authority was limited to matters committed in their presence and to the execution of warrants to arrest. The reverse gradually came to be the case. With the emergence and extension of the doctrine of arrest on probable cause, the discretionary power of the police was expanded, and apprehension came to dominate the organizational mandate. The focus of police practice and training shifted to conform to this exaggerated emphasis on arrest. Police academy training emphasized a knowledge of the criminal law, the apprehension of criminals, and the investigation of criminal matters. Peacekeeping and order-maintenance functions were given correlatively less emphasis. Instruction in peacekeeping and order maintenance was left to informal training on initial assignment to duty. ${ }^{4}$ Even today, little official attention is given to the following facts: the ordinary officer on patrol infrequently makes an arrest in his daily duty; ${ }^{5}$ citizen reporting behavior accounts for the large majority of all arrests by patrol officers; ${ }^{6}$ with regard to their onview arrests, ${ }^{7}$ most officers are concerned mainly with the matters of keeping the peace and insuring order in daily life; ${ }^{8}$ and police officers share a responsibility to prevent crime by their uniformed and visible presence on patrol. ${ }^{9}$ Enforcing the criminal law by detecting crimes and apprehending offenders, who are then turned over to the criminal justice system to be deterred by punishment, has become the principal business of the American police.

This strategic shift to an emphasis on apprehension and to a deterrence model of policing downgraded the compliance function of police departments. Formal police training, consequently, provided an officer with little instruction on how to secure compliance with the law or how to choose among alternatives when not invoking the power to arrest. In addition, managers often divested the organization of lower level tasks. For example, the enforcement of standing vehicle violations was thrust upon a new class of low status female employees called meter maids. Despite some divestiture, however, most compliance functions remained with police patrol, subject to informal

4. For excellent discussions of this informal training, see McNamara, Uncertainties in Police Work: The Relevance of Police Recruits ' Backgrounds and Training, in The Police: Six Sociological Essays 163, 163-252 (A. Bordua ed. 1967); H. Buckner, The Police: The Culture of a Social Control Agency 499 (1970) (Ph.D. dissertation, University of California, Berkeley), and J. van Maanen, Pledging the Police (1972) (Ph.D. dissertation, University of California, Irvine).

5. A Rand New York study reports an average arrest productivity of 0.22 Index crime arrests per man-month for uniformed patrol and 0.86 for detective patrol. P. Greenwood, AN ANalysis of The Apprehension Activities of the New York City Police Department 49 (New York City Rand Inst. 1970).

6. A. Reiss, The Police and the Public 84-114 (1971).

7. W. Spelman \& D. Brown, Calling the Police: Citizen Reporting of Serious Crime xxxxvi (Police Executive Research Forum 1981).

8. See A. Reiss, supra note 6, at 77-83.

9. See generally Reiss, Citizen Access to Criminal Justice, BRIT. J.L. \& Soc'y 50 (1974).

The very notion of a visible and uniformed patrol is more in line with peacekeeping, order maintenance, and crime prevention than it is with the model of proactive policing. In that model, detecting and investigating crimes often requires a force in civilian dress. The power of a police officer in plain clothes is derived from his passing as an ordinary citizen, whereas the power of uniformed police is derived from the visible signs of authority. 
rulemaking and to informal on-the-job training. Alternatives to arrest and the standards for determining whether there were alternatives became matters of low visibility. These matters were governed, in the last instance, by the discretionary authority that inheres in each individual police officer.

This article explores some of the consequences for contemporary policing of an historical shift from compliance to deterrence modes of policing. The exposition focuses upon how that shift affected the exercise of discretionary powers by police line officers and managers. Compliance and deterrence modes of law enforcement are compared in terms of their strategies and tactics for negotiation and intervention in the events of everyday life, their standards for processing information and violators, and the problems of securing officer compliance when enforcing the law and structuring their discretion so as to make them accountable to authority. The article concludes by suggesting that a mixed model of public policing utilizing the administrative law model of compliance enforcement as well as the criminal law model of deterrence policing may be a more effective organizational strategy of law enforcement. Several examples of ways to develop policing that emphasizes compliance are presented by examining control of vehicle safety and emissions, handguns, pimping and prostitution, juvenile loitering, and crimes associated with drunkenness.

II

Problematics in the Exercise of Police Discretion

\section{A. Perspectives on Police Discretion}

The problem of how to control police discretion in enforcing the law usually is treated in terms of police decisions to arrest or apprehend persons who are suspected or accused of violating the law. Considerable attention is given to police decisions not to invoke the criminal process ${ }^{10}$ and to the ways that legal rules and regulations govern enforcement decisions. ${ }^{11}$ Research on the decision not to invoke the criminal process centers upon the social organization of arrest, especially upon how situational elements, such as the deference and demeanor of the suspect towards the police, the preference of the complainant for arrest, and the social position of the suspect, affect the decision whether or not to arrest. ${ }^{12}$ Research regarding the legality of police conduct in making an arrest focuses on rule violations, such as circumvention of the

10. See, e.g., Goldstein, Police Discretion Not to Invoke the Criminal Process, 69 YALE L.J. 543 (1960).

11. See generally J. Skolnick, Justice Without Trial: Law Enforcement in Democratic Societr (1966); Stinchcombe, Institutions of Privacy in the Determination of Police Administrative Practice, 69 Aм. J. Soc. 150 (1963).

12. See generally A. Reiss, supra note 6; Black, The Social Organization of Arrest, 23 STAN. L. REv. 1087 (1971); Black \& Reiss, Police Control of Juveniles, 35 Am. Soc. Rev. 63 (1970); Pilavin \& Briar, Police Encounters with Juveniles, 70 AM. J. Soc. 206 (1964); Sherman, Causes of Police Behavior: The Current State of Quantitative Research, $17 \mathrm{~J}$. Research Crime \& Deling. 69 (1980); R. Friedrich, The Impact of Organizational, Individual, and Situational Factors on Police Behavior (1977) (unpublished Ph.D. dissertation, available at University of Michigan, Ann Arbor, Dept. of Political Science). 
exclusionary ${ }^{13}$ or interrogation rules, ${ }^{14}$ and on the illegal use of force. ${ }^{15}$

It has long been apparent that neither of these dominant emphases exhausts the ways our public police exercise discretion. Attention has been called repeatedly to the ways in which the exercise of police discretion varies with organizational mandates. Since the works of Banton, ${ }^{16}$ it has been commonplace to distinguish the peacekeeping or order-maintenance functions from the law enforcement functions of our public police. The ways in which police exercise their discretion are also determined by how they are mobilized, whether on their own authority (proactive mobilization) or on citizen initiative (reactive mobilization). ${ }^{17}$ Wilson concludes that the two major situational determinants of police discretion are whether police response is internally invoked or citizen-initiated and whether it is a law enforcement or order maintenance situation. ${ }^{18}$ These two situational determinants combine to create four types of discretionary situations for law enforcement officers: proactive and reactive law enforcement and proactive and reactive order maintenance. ${ }^{19}$

Not only does the nature of situations affect discretion in enforcing the law, but managerial influence also determines which kinds of discretion characterize law enforcement within an organization. Wilson concludes that police departments vary considerably in the emphasis that they place upon various forms of situational discretion. Communities are said to have a watchman style of policing when the defining characteristic of the policeman's role is to deal with less serious crimes by order maintenance rather than by arrest. ${ }^{20}$ In contrast, where the dominant police role is to deal with all violations of the law by arrest, the style of the department is legalistic. ${ }^{21}$ When crime is not a major problem and the police can concentrate on maintaining order and servicing citizen demands, Wilson characterizes the departmental style of law enforcement as one of service. ${ }^{22}$ Thus, organizational mandates governing a policeman's role and managerial discretion to emphasize an organizational style of policing are additional determinants of police discretion.

The view that there is a simple discretionary decision to arrest in order to enforce the law or to fail to arrest in order to keep the peace has been challenged as an oversimplification on yet other grounds. Bittner contends that

13. See generally SKoLNick, supra note 11.

14. Reiss \& Black, Interrogation and the Criminal Process, 374 AnNals 47 (1967).

15. Reiss, Police Brutality-Answers to Key Questions, 5 Trans-Action, July/Aug. 1968, at 2, 10-19.

16. M. Banton, The Policeman and the Community (1964).

17. Reiss \& Bordua, supra note 3 , at $29,45$.

18. J. Wilson, supra note 3 , at 84 .

19. Wilson identifies four types of discretionary situations depending upon whether the basis of police response is a police-invoked or citizen-invoked action and whether the nature of the situation is one of law enforcement or order maintenance. Id. at 85. Reiss \& Bordua, supra note 3, at 29, develop a more general model of law based upon whether the legal process is organized for proactive or reactive mobilization of legal agents and whether the action seeks civil remedies or the imposition of criminal sanctions.

20. J. Wilson, supra note 3 , at 140.

21. Id. at 172.

22. Id. at 200 . 
"[t]he real reason behind an arrest is virtually always the actual state of particular social situations" 23 and that "it is only speciously true to say that the law determined the act of apprehension, and much more correct to say that the law made the action possible." 24 He states in a related vein that "[t]he effective reasons for the action are not located in the formulas of statutes but in considerations that are related to established practices of dealing informally with problems." 25 What seems clear from Bittner's work with mentally ill and skid row persons is that, in situations in which police may choose how to behave, discretion is a matter of choosing among alternative courses of action, such as arrest and ordering behavior. A major focus of this article is an exploration of both how alternative courses of action are structured for police and how they come to be defined and chosen.

\section{B. Managerial Discretion}

There is some tendency to confuse the exercise of discretion by police managers with that of discretion by officers in the course of duty. Managers exercise discretionary powers in setting and implementing policies in five areas: (1) which laws are to be enforced and by what means; (2) the deployment of manpower and other resources to carry out policy mandates; (3) the selection, duty assignment, promotion, and training of personnel; (4) the structure of staff and the command and assignment of responsibilities to officers; and (5) the internal affairs of the department, especially regarding the conduct of officers. The discretionary powers of any individual officer depend upon the office that he occupies in the staff of command, together with such informal powers as he may accrue. Line officers commonly exercise the discretionary powers of formal authority as well as those powers of informal authority derived from line culture.

Although all police powers are not formally ministerial, the law constrains discretionary power under constitutional provisions and statutory law. As an example, the discretionary power of police managers to hire is constrained by legal requirements that prospective employees be given equal opportunity for employment. These constraints on hiring, in turn, affect other areas of discretion such as promotion and deployment of manpower.

Managerial decisions about which laws to enforce seem most open to discretionary choice under the law, since these decisions are not subject to the constraints of mandamus and are most likely to be constrained by accountability to political authority. Line officer powers, while organizationally ministerial, are practically judicial. It will be worthwhile, then, to distinguish managerial from officer discretion and to take the informal as well as formal organization of line authority into account. For the sake of economy, much of

23. Bittner, The Police on Skid-Row: A Study of Peace Keeping, 32 Am. Soc. Rev. 699, 714 (1967).

24. Bittner, Police Discretion in Emergency Apprehension of Mentally Ill Persons, 14 Soc. Probs. 278, 291 (1967).

25. Id. 
the discussion in this article is limited to either top management or the line officer on patrol.

\section{The Discretion of Agents and Inspectors}

One other line of inquiry into discretionary law enforcement is worth noting because it draws attention to how contemporary views of discretionary law enforcement have beer molded by attending primarily to the public police and the law of arrest. A growing body of research on municipal code enforcement, beginning with the work of Mileski, ${ }^{26}$ and on regulatory agencies draws attention to another cadre of law enforcement officers-agents and inspectors-who have discretionary powers to enforce the law. Although some have the power to arrest, most do not. These officers and their agencies, however, have enormous sanctioning powers at their command and can exercise choice in determining whether, when, and how to achieve the objectives of law enforcement.

Consideration of the discretionary power of regulatory agents leads us to regard police enforcement of law in terms of the major objectives of law and law enforcement. It will be examined below how compliance strategies of administrative law agencies and deterrence strategies of criminal justice agencies structure alternative courses of action for law enforcement agents and how in practice our public police face dilemmas in being held formally accountable for compliance under the criminal law while often following the compliance model under the color of administrative law.

\section{III}

\section{The Nature of Police Discretion}

The idea of discretion is associated with the making of decisions and implies that a decisionmaker can make choices among alternative courses of action. Police are said to have discretion because they can choose not to arrest someone who qualifies for arrest under the law. Alternatively, it can be said that the police have discretion in instances in which the law does not specifically determine which among alternative courses of action must be selected in a particular situation. For example, in a situation in which an officer might impede the orderly flow of traffic by arresting a motorist for a moving violation, the officer may decide against arrest because he considers the alternative responsibility of keeping the traffic moving to be more important and because both are lawful choices. This example reveals a number of different aspects of the meaning of the term police discretion. One is quite simply that an officer who has discretion has the power to choose among alternatives. A second and closely related aspect is that a choice made by an officer in the exercise of his discretion must be permitted by the authority of the law.

26. M. Mileski, Policing Slum Landlords: An Observation Study of Administrative Control 216 (1971) (Ph.D. dissertation, Yale University). 
A third is that an officer who has discretion exercises individual judgment in making a choice.

With regard to the first aspect, when line-police discretion is viewed as the power to choose among alternatives, it is apparent that the choice an officer will make depends upon the number and kinds of alternative courses of action available to him. Quite commonly, line police officers regard arrest as but one of a number of possible courses of action. Moreover, the possibility of arrest remains while the officer is negotiating or choosing among other courses of action. The greater the number of alternatives open to an officer in handling any police matter, the greater are both the officer's freedom to choose and his ability to negotiate a course of action or exercise the powers of a compliance rather than a deterrence agent. In addition, the less likely it is that any consequences will befall the officer for choosing among these different courses of action, the less likely it is that the officer will enforce the law by arrest.

The second aspect of police discretion raises the issue of whether or not an officer making a choice can be held legally or administratively accountable for his action. It is said that the decision to arrest is at least nominally reviewable, whereas the decision not to arrest ordinarily is not. One could argue that all decisions not to arrest are potentially reviewable as matters of tort liability, if not by formal agency review. What is problematic, however, is that even though all decisions are de jure open to review, in reality most are not reviewed and perhaps, given the dispersed nature of a typical police command, never can be. Review, moreover, is necessarily a retrospective act. It can operate prospectively only to the extent that the prospect of review commands a deterrent power on the risk assumed by a decisionmaker. One may, for example, deter police officers from unduly using force by increasing the review of actions in which force has been taken and by sanctioning officers for discretionary actions when force is retrospectively regarded as excessive. Nevertheless, because retrospective actions require the social reconstruction of past behavior, informal rules often arise that anticipate reconstruction in review. These informal rules of officers subject to review are designed to reconstruct reality in terms that are favorable to an officer's actions. They advise officers to cover actions in which a suspect sustains injury by filing charges of interfering with or resisting an arrest or charges of an assault on a police officer. ${ }^{27}$ They prescribe that officers should control the release of information about incidents in their reports. Defensive report writing includes constructing an account that justifies the action an officer reports taking. ${ }^{28}$

As for the third aspect of police discretion, the making of an arrest is rarely a simple decision. In making an arrest, an officer must make decisions about alternative courses of action, such as whether it is necessary to apply force of some kind, whether it is necessary to search the person for the officer's pro-

27. A. ReISs, supra note 6 , at 55 .

28. Chatterton, Police Work and Assault Charges, in Control in the Police Organization 194, 201 (M. Punch ed. 1983). 
tection, whether it is necessary to segregate the suspect when transporting him in order to protect others, and whether to pursue the person in flight. While all of these considerations may be regarded at law as matters of sustaining the power of the arrest, or actions contingent upon the arrest in order to protect the safety of the suspect, the officer, or others, the presence of the alternatives indicates that what constitutes an arrest decision at law may add up to many sequential choices by one or more officers. This fact exacerbates the problem, discussed in the paragraph above, of maintaining accountability through retrospective review and control by sanctions. Needless to say, as Bittner and others have argued, the problem may be far more complex if one is dealing with less serious matters in which peacekeeping is at stake. ${ }^{29}$

The core problem in accountability, however, may not be retrospective review and control by sanctions-deterrence-but rather, prospective control over the officer's behavior-compliance. At the core of guiding police discretion, then, is a determination of how to achieve this compliance. Previous research on police discretion in making an arrest emphasizes officer compliance with informal work group norms and systems of peer and supervisory control rather than officer compliance with the procedural requirements of law or with the written rules and procedures of the police department. Consequently, much more is known about how officer decisions are shaped by the desire to minimize trouble with co-workers and supervisors than about how decisions are made to enforce a particular law and how informal, rather than formal, performance standards are met. ${ }^{30}$

\section{IV}

\section{Compliance and Deterrence as Generic Strategies of Social Control}

Compliance and deterrence strategies of law enforcement have different objectives. The principal objective of compliance law enforcement is to secure conformity with law by resorting to means that induce conformity or by taking actions to prevent law violations without the necessity of detecting, processing, and penalizing violators. The principal objective of deterrence law enforcement is to secure conformity with the law by detecting violations of the law, determining who is responsible for the violations, and penalizing violators to inhibit future violations by those who are punished and to inhibit those who might be inclined to violate the law if violators were not penalized. There are two principal types of compliance strategies of law enforcement, one based on incentives to comply, and the other on threats to invoke penalties for noncompliance unless actions to comply are taken. Compliance is voluntary in incentive-based systems whereas it is to some degree coerced in threatbased systems.

29. Bittner, supra note 24, at 286-87.

30. See van Maanen, Observations on the Makings of Policemen, 32 Hum. Organization 150 (1973); van Maanen, Working the Street, in The Potential for Reform of Criminal Justice 83 (1974). 


\section{A. What is Compliance?}

The definition of compliance is problematic because it necessarily involves decisions about how variations in behavior and motives fit rules or norms and how rules are promulgated to encompass behavior that, for some reason, has been determined to lie outside a given rule. ${ }^{31}$ The definition of compliance also depends upon whether it is viewed from the perspective of the compliance agency or of those made to conform to its standards. Pfeffer and Salancik view compliance from the perspective of those complying as "a loss of discretion, a constraint, and an admission of limited autonomy." 32 This is a somewhat different perspective from that of controllers who, although they may regard their actions as constraints, view them as necessary to insure that behavior conforms to their standards.

From the perspective of law enforcement agents, then, compliance means conforming behavior to a standard of conduct that is set by normative or political means. One thinks of compliance in terms of a threshold where there is a state of compliance below the threshold (some level of risk that is acceptable) and noncompliance above it (an unacceptable risk). ${ }^{33}$ Often, in practice, thresholds of acceptable risk cannot be attained immediately, either because the threshold is unattainable, except over time, or because the threshold itself is negotiable. Given a distribution of risk, conformity is a matter of selecting a threshold that defines an acceptable risk.

\section{B. Standards or Tests of Compliance}

Compliance depends upon the measure of risk of harm as well as upon its standard. A legal standard generally recognizes only some threshold of risk, leaving its precise determination open to administrative or judicial rulemaking. Yet, threshold measures of risk often are unobtainable or lack accuracy in any precise sense of instrumentation. It is difficult, for example, to know how much risk is posed by gun carrying in a population. The risk of being harmed by legal and illegal gun carrying is not easily estimated, since there is limited knowledge about gun carrying. Any conclusion, then, about the potential harm that can result from a person carrying a gun becomes a matter of judgment.

Tests to determine compliance also vary in their precision. Compare the difference in results from tests for drunkenness based on smelling the breath or observing a person walking a straight line with the results of breathalizer, blood, and urine tests for alcohol. Tests for speeding similarly may construct

31. For a more extended treatment of this problem and Catch-22 in discretionary justice, see Reiss, Book Review, 68 Mich. L. Rev. 789 (1970) (reviewing K. Davis, Discretionary Justice: A Preliminary Inquiry (1969)).

32. J. Pfeffer \& G. Salancik, The External Control of Organizations: A Resource Dependence Perspective 94 (1978).

33. W. Lowrancek, Of Acceptable Risk: Science and the Determination of Safety 75 (1976). 
reality differently when the tests are an officer's judgment of speed as opposed to the use of a police vehicle speedometer or radar.

The less precise any test of compliance is, the more discretion a law enforcement agent has to determine compliance. Moreover, the more tests that an agent has at his disposal to determine the level or threshold of compliance, the more the agent is open to negotiation of what constitutes compliance. Thus, the determination of what is compliance generally rests in the social construction and reconstruction of reality by control agents and by those they seek to control. ${ }^{34}$

A major issue in compliance is when to intervene to alter the risk of harm. The more immediate and visible the harm is, and the more it is assumed that harm can result or continue, the more one must consider immediate intervention. Where victims are less visible and less determinate, and where the consequences of harm are less immediate and visible, noncompliance states of longer duration are permitted. It is useful to classify events requiring immediate attention as accidental or unintentional precisely because raising issues of intent complicates handling the immediate requirements of the event. Giving immediate attention to intent diverts resources from handling the emergency to investigating issues of compliance and control. Observe how ordinarily some compliance issues, particularly responsibility for the event and the subsequent prevention of its recurrence, loom beyond each event defined as an emergency or as leading to an emergency. The nuclear generating facility must file a report of its investigation for each and every failure, no matter how trivial, once the immediate requirements of the situation have been handled. The fire or police department will gather evidence to decide whether a fire involves the crime of arson after the fire is under control or extinguished; the police officer on duty or the auto accident investigation bureau will complete an auto accident investigation or advise the parties to do so once the scene of the accident has been ordered and emergency requirements met.

\section{What is Deterrence?}

Deterrence can be regarded as the effect of a sanction or the threat of its imposition in inhibiting the behavior of the sanctioned person or of others who would commit like behavior. ${ }^{35}$ Andenaes distinguishes between the effect of the threat of punishment-general deterrence-and the effect of the imposition of punishment-special deterrence. ${ }^{36}$ It would seem that fear of punishment can arise either from its imposition or from the threat to invoke it. Persons are considered to be deterred from entering a population of violators if they perceive punishment as a threat or experience it vicariously.

34. Hawkins, Bargain and Bluff: Compliance Strategy and Deterrence in the Enforcement of Regulation, 5 LAW \& POL'Y Q. 35 (1983).

35. A. Blumstein, J. Cohen \& D. Nagin, Introduction, in DeterRence and InCaPacrtation: Estimating the Effects of Criminal Sanctions on Crime Rates 1, 16 (1978).

36. J. Andenaes, Punishment and Deterrence 84 (1974). 
Basic to the theory of deterrence is the causal assumption that the cost of punishment and its threat, or its cost relative to any gains, has the power to inhibit unlawful behavior by encouraging potential offenders to minimize loss. The presumption in deterrence, then, is that individual behavior is rational to the degree that it responds to incentives and disincentives, particularly to the disincentives of negative sanctions.

Both compliance and deterrence seek conformity to the law. They differ primarily in the conditions and means of achieving that result. Compliance systems aim to prevent violations of the law from happening or to reduce their harmful consequences. Deterrence systems must allow violations of the law to occur so that those violations can be punished to produce the deterrent effect. The cost of deterrence is always some violation of the law. In the Durkheimian sense, some violation of the law must always occur, since the punishment of violations is essential to the maintenance of a normative system. ${ }^{37}$ Without the example of punishment, the collective sentiments and conscience weaken and lose their control. ${ }^{38}$

\section{Law Enforcement in Everyday Life}

Most people rarely have encounters with the police that result in an apprehension or arrest. Although the lifetime prevalence rate of juvenile apprehension and adult summons or arrest is substantial, ${ }^{39}$ the annual rate of criminal law enforcement actions is low. ${ }^{40}$ When the criminal law is invoked against citizens, it is more likely to be for a minor rather than a major offense. ${ }^{41}$ The rate of apprehension, to be sure, is greater for lower than middle class citizens, owing both to the selective nature of law enforcement and the higher rate of violation found in the lower socioeconomic class. Yet, most U.S. citizens, regardless of class, do not experience a criminal law enforcement action, including those involving traffic and vehicle-related offenses, even once a year.

Although ordinary citizens do not experience criminal law enforcement actions in their daily life, an individual has a much higher probability of experiencing a host of compliance law enforcement actions. The ordinary citizen is unaware of experiencing many of these as law enforcement or tests of compliance, even when they involve face-to-face encounters. For example, one's car must be registered and licensed and, in many jurisdictions, is subject to an emissions test and a safety inspection. Although most are found in compliance, corrective action must be taken when there is noncompliance. To board most aircraft, one must pass a metal detection test and sometimes be subject to a physical inspection. To exercise one's right to vote, one must register

37. E. Durkheim, The Rules of Sociological Method 65 (2d ed. 1902).

38. Id. at 68.

39. Blumstein \& Graddy, Prevalence and Recidivism in Index Arrests: A Feedback Model, 16 L. \& Soc'Y REv. 265, 265-68 (1981-82).

40. Excluding traffic offenses, the 1981 arrest rate was about five per one hundred inhabitants. Sep Federal Bureau of Investigation, 1981 Uniform Crime Reports 163, table 24.

41. The ratio of arrests for indexed to nonindexed crimes was roughly 1:5 in 1981. See id. 
and must present proof of identity, if requested, at the time of voting. One may be required to produce proof of age to be served alcoholic beverages. To be eligible for many federal benefits, one must submit evidence of eligibility. One must file one's tax return and comply with IRS requirements for reporting income and payment of taxes. Many places, such as the Oval Office, an airport departure lounge, a police headquarters, and a prison, cannot be entered without some search of the person. Many employees must wear an identification badge to be admitted to their place of employment. ${ }^{42}$ The responsibility for enforcing compliance in these situations rests in a host of administrative agencies and their law enforcement officials, usually dubbed agents or inspectors rather than police. On an ordinary day, far more citizens are subject to compliance actions than to deterrence actions and their behavior is more often subject to administrative than criminal law actions. In a single day the number of persons who must comply with an airport screening, an IRS audit, an eligibility screening for benefits, or a motor vehicle inspection is far greater than the number who will be subject to a public police action. Whereas criminal law enforcement falls more heavily upon the lower class, it is likely that compliance actions fall more heavily upon the middle classes. Indeed, while many think of administrative law enforcement as consisting of actions against organizations, many more enforcement actions are taken against individuals.

It was noted above that our public police are engaged in peacekeeping and order-maintenance functions. It now can be seen that many of these functions are more properly viewed as compliance- rather than deterrence-based law enforcement actions. In the aggregate, police are more likely to exact coerced rather than voluntary compliance in encounters. In addition, coerced compliance predominates over deterrence by arrest in the behavior of officers on patrol. ${ }^{43}$ Our public police force faces a dilemma, however. Many compliance-based actions are without legitimation by police organizations and training for compliance-based law enforcement is lacking. The following section compares compliance- with deterrence-based law enforcement strategies and tactics.

\section{V}

Some Comparisons of Compliance with Deterrence Law Enforcement Strategies and Tactics

\section{A. Negotiation Tactics}

Compliance enforcement is often regarded as essentially a bargaining or negotiating strategy between agents and violators. Both the standards and

42. In addition to these public system compliance tests, citizens in mass democratic societies must pass many private system compliance tests. In an age of credit, bank checks, and registration, one is frequently called upon to identify oneself to private as well as public workers.

43. There is also an informal system of deterrence-based justice in public policing that arises because officers are alienated from the formal criminal justice system. See A. REiss, supra note 6, at 138. 
timing of compliance may be negotiated. ${ }^{44}$ Threats of punishment are an important tool of the agent in negotiating compliance. Agents can bluff when backed by threats of punishment. ${ }^{45}$ Bargaining and negotiation can be used, however, in both compliance- and deterrence-based systems. These tactics have come to dominate public prosecution in the United States. Negotiation over what consitutes the charge supplants real-offense charging, and plea negotiation between prosecutor and defense counsel over the recommended penalty or the choice of a charge in terms of its penalty affects sentencing. Such negotiations are largely, although indirectly, coerced by system constraints, but they appear to be voluntary choices in each individual case. Probation and parole represent coercive forms of compliance that are similarly aimed at a large number of individual cases. They are loosely structured practices mixing formal compliance routines with negotiation on technical violations, such as the timing of reporting, or on infractions of the conditions of probation or parole.

Bargaining and negotiation often are used as tactics in making a decision whether or not to arrest. When the police seek information, they may turn persons subject to arrest into informants in exchange for a lesser charge or release from arrest. ${ }^{46}$ They may even pay informants and permit them to continue committing crimes in exchange for information. ${ }^{47}$ In addition, the police may bargain with the victim or other complainant over the offender's fate. ${ }^{48}$ In general, law enforcement agents tend to resort to settlement bargaining in encounters in which arrests may be made. The most common form of dispute is a disturbance in which keeping the peace is at issue. ${ }^{49}$ Police may, for example, negotiate with a party to reduce noise. Assaults between persons in public and private places often are settled by an officer negotiating with the parties to the dispute. ${ }^{50}$

Compliance- and deterrence-based systems differ primarily in how the exercise of discretion is formally organized and of how decisionmakers are held formally accountable for their decisions. Agents conducting an investigation for a violation of criminal law are subject to far more constraints at law than those investigating a violation of administrative rules. Also, the behavior of an enforcement agent has greater consequences for a procedural determination in a proceeding at criminal law than one in administrative law. A few of these differences in standards, powers of officers, strategies of enforcement, and accountability for enforcement officers in deterrence-based (i.e., criminal law), as compared with compliance-based (i.e., administrative law), enforcement are considered next.

44. Hawkins, supra note 34 , at 41-42.

45. Id. at $49-50$.

46. For an especially good account of this process, see J. SKolnick, supra note 11, at 112-13.

47. Id. at 124,127 .

48. D. Black, The Manners and Customs of the Police 92 (1980).

49. Id. at 119 .

50. See id. at 131-32; Sherman \& Berk, The Specific Effects of Arrest for Domestic Assault, 49 Am. Soc. REv. 262 (1984). 


\section{B. Standards for Processing Information and Violators}

Legal systems are organized as dual processing systems: they process both information and people. Often, information and people are processed together, although information on violations may be processed without any knowledge of who committed the violations and, in appellate proceedings, the system processes only information. Law enforcement systems, then, process people and organizations as well as information about violations separately and conjointly.

The consequences for ordinary citizens differ considerably depending upon whether people and information are processed in a compliance or a deterrence law enforcement action. While one normally regards police actions as coercive and compliance actions as voluntary, the distinction is blurred for ordinary citizens. The search of one's person and property can be far more intrusive and public in an airport screening, for example, than it would be upon arrest. Moreover, there are more evidentiary safeguards for a search incident to arrest than in most compliance searches, such as those in boarding an aircraft or having one's person or luggage searched by passport control.

The standards of evidence likewise vary considerably between administrative and criminal law matters. The standard of "proof beyond a reasonable doubt" in criminal matters is replaced by a much less stringent "preponderance of evidence" standard in administrative law hearings.

The standards of volition applicable in determining blameworthiness likewise vary between the two systems. Criminal law matters require proof of intent, whereas many administrative law matters require only evidence of "willful" violation or even simply a finding that the violative act was not inadvertent or unintentional. Where notions of strict liability apply, and one can be held liable solely by virtue of one's position as an agent responsible for the behavior that constitutes the violation, the standard shifts to a demonstration of responsibility.

The rights of defendants also are generally more circumscribed in administrative than in criminal law matters. If one invokes fifth amendment rights in administrative law matters, for example, there ordinarily is no protection from adverse inferences. Individuals and organizations thus are more vulnerable to incurring sanctions when invoking that right.

Often, however, the two systems are more alike than they are different in their standards and strategies of law enforcement. In both systems, persons are often scrutinized without any awareness of whether they are being processed for potential violation of the law. One is unlikely to know that he has been processed for an IRS audit or a police radar screening for speeding unless he is found in violation or advised that he is under investigation for a violation of law. Compliance screening is as integral to a deterrence-based system of law enforcement as it is to one that is compliance-based. 
C. Strategies of Intervention in Events

A central and continuing problem in both compliance- and deterrencebased systems is whether one is able to or ought to incapacitate violators or take actions that stem directly from the harm that the violators are causing. The more central any violator is to the maintenance of a system, as judged by enforcers, the less likely those enforcers are to pursue strategies that risk incapacitating such a violator, and the more likely they are to opt for compliance. ${ }^{51}$ This may account in part for why business people may be given more favorable treatment by enforcement agents for both administrative and criminal law violations.

Compliance systems seek to create law-abidingness and rely on preventive or remedial actions. Deterrence-based law enforcement agents, by contrast, observe or inspect for conformity since their objective is to detect noncompliance. Having detected a violation of the law and apprehended a violator, compliance-based systems seek correction, whereas those systems based on deterrence seek punishment to prevent future violations or simply to incapacitate violators as a just dessert. Put another way, the problem of compliance agents when they discover noncompliance is whether, when, and how to report the violation and whether and in what ways to induce the violator to come into conformity with the law. Such decisions require an exercise of discretionary authority.

Few remedial or corrective actions may be considered necessary in some compliance systems. Licensing systems, for example, are based on the presumption that compliance with practice requirements essential to obtaining the license is the primary control over malpractice. Nevertheless, licensed individuals who violate practice rules are subject to coercive compliance systems that rely on threats of deterrence-based punishment. Normally, such punishments are invoked only in the relatively rare event of violation. Licensed-based systems, then, are normally coercive compliance systems based on the threat of revoking a license. Licensing of the sale of alcoholic beverages and of explosives are other examples of attempts to control potential criminal law violations by licensing authority.

A main objective of compliance systems is to keep risks of harm at acceptable levels. A compliant organization is at that minimally acceptable level. Unlike deterrence-based agencies that gauge their success in terms of numbers of violations detected and violators punished, a compliance-based agency calculates success in terms of numbers in compliance. Its goal is to certify compliance. A parallel goal is to reduce the likelihood that harm will result, an objective that is reached by attending to causal or conditional states that

51. Organizations, as well as their members, can be incapacitated. They can be prohibited from taking actions as organizations for periods of time, divested of a part of their capacity, and even put out of operation altogether by sanctioning agents. 
change the probability of harm. The nature of a core violation of a compliance-based system of social control is technical rather than immediately harmful.

Consequently, inspectors in compliance systems exist to detect and certify compliance. They are there to assure, for example, that a motor vehicle meets safety standards, that a driver knows how to operate a motor vehicle lawfully, or that premises are safe for occupancy. They likewise inspect for technical violations that increase the probability of harm if uncorrected. Inspectors direct their attention to matters such as whether emergency exit signs are working properly, whether a vehicle has been reinspected for safety, or whether a business is open only during licensed hours. Failure to meet these conditions is treated as a technical violation that presages possible harms, respectively, of loss of life in a fire, a harmful accident, or illegal sales. Even when the inspector detects harmful violations, such as the marketing of foods with PCB levels above the standard for safe consumption, the object is either to alter the conditions that produce the violations or to remove the sources of the violations from the market to prevent harm. Although compliance systems achieve compliance by remedy, remedy is not the core of a compliance system; its core is the certification of compliance and the maintenance of conditions following their remedy. A compliance system fails of its goal when it must repeatedly seek remedy.

Despite the centrality of maintaining compliance, the agents of operating compliance agencies seem to prefer enforcing actions to certifying compliance if for no other reason than that the "working action" lies there. Enforcing actions, thus, mistakenly can be seen as the work of compliance when they are not, just as police actions of arrest and court actions of sanctioning are not the work of law-abidingness. Paradoxically, in the policing of common crime, the public police likewise prefer nonconformity to conformity. Their competitors in private policing, however, are compliance- and discipline-centered, a factor that may figure in the latter's substantial growth and explain how their work accomplishes the ends of the private organizations which employ them. Private organizations ordinarily seek compliance, not deterrence. ${ }^{52}$

Presently, formal compliance strategies are directed more toward controlling the conduct of groups and formal organizations, while informal compliance and deterrence strategies are directed more toward controlling the conduct of individuals. Deterrence systems may be strategically adapted to common crime given their limited and infrequent contact with violators, whereas compliance systems seem strategically more adapted to coping with organizational violations of law where continuing contact with violators is possible. Despite these central tendencies for the two strategies, many law enforcement agencies find that mixed strategies are preferable to single strategies. The criminal justice system and police organization management

52. Shearing \& Stenning, Modern Private Security: Its Growth and Implications, in Crime AND Justice: An Annual Review 193, $214-15$ (1981); Shearing \& Stenning, Snowflakes or Good Pinches? Private Security's Contribution to Modern Policing, in The Maintenance of Order in Society 96, 99-101 (R. Donelan ed. 1982). 
emphasis on deterrence strategies appears to be less than optimal. The largely informal police officer strategies oriented towards coerced compliance attest to the limitations of the single deterrence strategy. What needs to be considered, then, is how to formalize the compliance strategies of our public police so that their actions may be more accountable and so that their discretion in enforcing the law may be governed by formal training.

\section{The Powers of Agents}

One other difference between compliance- and deterrence-systems lies in the power given to law enforcement agents to determine states of compliance with the law. In compliance systems, agents, especially inspectors, are obliged to determine whether there is compliance as well as to detect violations of the law that may serve as a basis for coercing compliance.

Compliance enforcement agents also are given the power to investigate situations in which they have every reason to conclude that compliance exists and in which there is no probable cause to conclude that there is any violation of the law. Inspectors often are given rights to enter even private places without prior notice and to intrude in a variety of ways into the private matters of those places-matters and places where the public is forbidden. They may be privy to organizational secrets in carrying out their duties and obligated not to disclose them.

One of the main tasks of agents in compliance sytems is to certify states of compliance. Inspection and certification are parts of a system of public protection that is designed to reduce the likelihood of harm. The inspector of elevators, for example, assures by inspection and notice the safety of the elevator at the time of inspection. If he detects a violation he may ask for certain changes or repairs and set a date for re-inspection to see whether there is compliance.

Above all, under certain circumstances and in certain kinds of law enforcement or regulation, inspectors are given the power to sanction law violators and even to choose among the sanctions that can be meted out, including, for some agents, the power to arrest. Such sanctions can be very consequential and can impose a substantial punishment or harm upon individuals and organizations. A mine safety inspector, for example, may order a mine closed with immediate and material consequences for the employment of workers and the profitability of an organization. Indeed, one might say that under some circumstances, compliance agents have the major power to punish organizations since few enforcement actions are ever formally adjudicated either by administrative law judges or by the courts.

Also characteristic of compliance enforcement agents is the discretionary power to negotiate both compliance with the law and the nature of the sanctions to be imposed. This power may be formally granted to the inspector by law, formally delegated by the agency, or exercised informally by the agent within the population over which he exercises a measure of control. In any case, this power to control the choice of the sanction and to negotiate the 
effect of its consequences gives agents a powerful tool with which to secure compliance with the law.

The public police ordinarily are formally given only the single power to sanction by arrest. Still, they may affect the kind and amount of sanctions for less serious infractions of law. Thus, traffic officers and police on patrol issue summonses to which fines are attached. They have considerable latitude in choosing just how many of the actual violations will be cited and hence they determine the amount and level of the sanction given (unless the violator chooses to make a court appearance). This discretionary power to sanction by summons, although a judicial power de jure, rests de facto in police officers. Additionally, state legislatures may provide for a citation system that explicitly recognizes the exercise of police discretion. ${ }^{53}$

The greater the range of sanctions that officers can impose to achieve compliance or deterrence, the greater becomes their discretionary power. Again, traffic law enforcement may serve as a case in point. When officers are empowered to give warning tickets, as well as to issue summonses, their discretionary power in traffic enforcement is enhanced. They may choose the more compliance-oriented citation of a warning over the deterrence- oriented official summons that carries with it a predetermined sanction (unless the alleged violator exercises his right to a court appearance). Additionally, the power to tow vehicles for violations adds to the discretionary power of the police. A vehicle tow may be a more powerful general and specific deterrent than is a summons with a fine. The combination of such sanctions may be especially powerful and, in some jurisdictions, it is within an officer's power to decide whether a vehicle shall be towed, a summons given, or simply a warning violation issued. Citations, moreover, may be issued if either a vehicle or an operator is in a state of noncompliance.

The power and responsibility for detecting and determining violations of law and for deciding about and imposing sanctions for those violations can be lodged in the same or different functionaries within an organization or divided among organizations. In our criminal justice system, for example, these powers are distributed among executive and judicial agencies and among different functionaries within agencies. Ordinarily all of these powers are lodged within the same organization for administrative law violations. The more that the detection of violations is separated from the determination of sanctions, and the more that determination is separated from the actual imposition of those sanctions, the less opportunity law enforcement agents have to negotiate compliance or to choose among alternative punishments. Even when decisions concerning the detection and determination of violations are separated organizationally from decisions about what sanctions to impose and how to carry them out, organizations may vary considerably in the

53. Only a minority of the states, however, have adopted a citation system that gives the police discretion to decide how violators are to be processed in a criminal justice system. For a discussion of the citation system and its relationship to police discretion, see Williams, Police Discretion: The Institutional Dilemma-Who Is In Charge?, 68 Iowa L. REv. 431, 451-52 (1983). 
power given to the enforcement agent to influence the sanctioning decision. Generally speaking, compliance-based agencies give their law enforcement agents more power to influence the decisions about what violation is to be charged and what sanctions should be imposed in the cases an agent has brought forward than do deterrence-based organizations.

Compliance enforcement agents often do not control either the determination of what sanctions to impose or their actual imposition. Nevertheless, their advice and testimony is sought regarding the nature of those sanctions. The agency deems them closest to the situation and relies on their advice to determine how to achieve compliance or whether to punish.

Quite the opposite is the case for the public police. They are constrained to offer only the information that will be wanted by other responsible agents in the criminal justice system. They are expected to provide information relevant to proof of the state's case against the defendent, or to provide information to determine whether they or other officers acted in compliance with the law. The information on officers' compliance is considered relevant both to sanctioning the officer and to deciding whether or not the violator should be sanctioned. The officer's testimony is considered relevant only to factual determinations, and no provision is made for him to offer an opinion at the time of sentencing when there is a finding of guilt. It is not altogether clear why the police officer's opinions are not solicited at the time of sentencing since often those of the prosecutor, defense counsel, and, more recently, victims-all of whom are directly involved in factual determinations-are solicited by the bench.

Thus, it is not only the formal separation of law enforcement from the adjudication of criminal matters in our criminal justice system but also the denial of any power to formally sanction or to participate in adjudication that leads police officers to develop their own informal system of discretionary justice. ${ }^{54}$ What is absent in the criminal justice system is present in varying degrees for legal agents in an administrative law system. Criminal law enforcement agents enter sanctioning decision processes only as passive agents, and often what is at issue is whether or not the agent has complied with the law. The criminal justice system seeks, then, largely to deter illegal behavior of both its police agents and potential violators. The compliance agent enforcement system, especially that of the inspectorate, has fewer such constraints.

\section{VI}

\section{The Organization of Law Enforcement}

\section{A. The Paradox of Police Officer Compliance}

Somewhat paradoxically, deterrence- and compliance-based law enforcement systems depend upon inducing compliant behavior in their law enforcement officers. The task for managers of a deterrence-based police agency is to

54. A. REISs, supra note 6 , at 114-20, 134-40. 
insure that its officers comply with departmental standards as well as standards of substantive criminal law and procedure.

Concern for the exercise of discretion in criminal justice or deterrencebased systems rests primarily in monitoring the behavior of line police officers. The historical shift to a deterrence model of policing, in which arrest is the major basis for initiating cases for criminal justice processing, results in the system focusing primarily upon the legality of police behavior attendant to arrest. The legality of arrest behavior thus has become central to the processing of cases through that system.

Attention often is called to the fact that the criminal justice system focuses on the legality of an officer's behavior and seeks to obtain officer compliance with the law of arrest. The way that officer behavior is dealt with when there is noncompliance, however, generally seems devised neither to deter the officer by direct punishment for failure to conform to rules nor to operate so as to insure compliance in future arrests. The assumption that officers will comply with legal rules for their behavior in order to avoid dismissal of charges or suppression of evidence seems without factual support. Indeed, it is questionable whether one would want to characterize officer compliance with the law of arrest as an objective of police and other criminal justice organizations, despite the centrality of arrest to their goals.

Within a few areas of police behavior, however, noncompliance is punished. A deterrence-based model is seen as a mechanism for controlling police conduct. Nowhere is this more apparent than in the approach to the control of police use of force, especially deadly force. Even in that instance, the threats of punishment come as much from external as from internal sources. A major objective of civil suits brought against police officers and their departments alleging illegal use of force is to deter officers from its use. Regardless of the outcome of such civil proceedings, they are a cost to the police organization and to the officers charged and are regarded as a deterrent because of this cost. These external pressures require the invocation of procedures for internal review and deterrence by punishment, diverting attention from the objective of how best to achieve officer compliance with the law. Punishment of officers for the improper use of force by fine, suspension, or expulsion may have a limited deterrent effect when the officer code of conduct regards such punishments for their exercise of discretion as unjust. A compliance-centered system that controls the exercise of discretion may be far more effective in controlling police conduct, as the following discussion of the control of the use of deadly force illustrates.

Recently, in American policing, some managers have come to question whether a deterrence-based system of punishment is necessary or sufficient to control police misconduct. The control of the use of deadly force has led to a reexamination of the effectiveness of punishment-centered systems. Initial attempts to control the use of deadly force focused on the statutes governing its use, especially provisions permitting the use of deadly force against fleeing 
felons. Where state statutes could not be changed, police commissioners and chiefs found that the same end could be accomplished through the issuance of department orders, using the threat of punishment for failure to obey orders as a basis for coerced compliance. These rules constrained the use of force to a small number of situations, such as the protection of the life of an officer or of others in immediate danger of serious injury by a felon..$^{55}$

Changes in statutes and rules were expected to provide clear alternatives: officer compliance with the law or coerced compliance by invoking punishment for misconduct. Misconduct is difficult to prove, however. The statutes and rules, moreover, left officers with considerable discretion to use force and the opportunity to affect the conditions for their own use of deadly force. In recognition of these problems, a number of police departments have shifted their focus from securing compliance by training officers "when to shoot" to training them in the exercise of discretionary authority. Although officer training in the exercise of discretionary authority clearly is one way to move towards a compliance-based system, it leaves unresolved the question of whether changes in internal organization and management of the system might not induce compliance by controlling the conditional exercise of discretion. Indeed, that kind of shift began to take place with the development of statutes and rules about the use of deadly force.

There are other alternatives, however, for controlling the exercise of discretion by individual officers as to whether or not to use deadly force. Much depends upon how decisionmaking is organized and how it is constrained by rules. Compliance often can be achieved by organizational means of making decisions. Nothing seems more likely to lead to the questionable use of deadly force than the absence of regularized procedures for making decisions in encounters that may involve the use of deadly force. Examination of encounters in which deadly force was used indicates that, in the large majority of them, there was no need to make a decision to use deadly force in an immediate sense, and in only a very small proportion was it necessary to use force to protect the life of officers or others who were in immediate danger. Indeed, threats to officers arise perhaps more from situations where the officers move towards confrontation than from de-escalation. ${ }^{56}$ There is growing agreement that the use of deadly force can be constrained by controlling decisions leading to its use, including hierarchial consideration of alternatives prior to the decision to shoot ${ }^{57}$ Compliance with rules for the exercise of discretion appears to depend upon the clarity of the operational rules of implementation, the amount of training officers receive in the application of these rules, and the extent of administrative control of decisions and review of

55. K. Matulia, A Balance of Forces (1982); Fyfe, Administrative Interventions on Police Shooting Discretion: An Empirical Examination, 7 J. Crim. Just. 309, 309-23 (1979); Sherman, Perspectives on Police Violence, 452 Annals 1, 9-10 (1980).

56. See Binder \& Scharf, The Violent Police-Citizen Encounter, 452 Annals 111, 112, 116 (1980).

57. P. Scharf \& A. Binder, The Badge and the Bullet 209 (1984); Reiss, Controlling Police Use of Deadly Force, 452 AnNals 122, 209-11 (1980). 
past conduct. ${ }^{58}$ Prevention lies in controlling choices that lead to a decision, and deterrence lies in review of that decision and of its consequences.

\section{B. Structuring Managerial and Officer Discretion}

Police organizations are loosely integrated with a host of different communities and with the public whom they serve. They are expected to maintain order in daily life, whether in the flow of traffic or in the prevention of disorder in human gatherings. More generally, they are expected to assure citizens that their environment is a safe one and to cope with citizens' fears of being victimized, as well as to deal with actual instances of victimization by crime. Moreover, police organizations are expected to control the quality of life in the community and to regulate the public peace. Additionally, the police may respond to a variety of demands for service. Perhaps because police organizations are more closely integrated with the criminal justice sytem than with the public, and perhaps because many communities are mosaics of conflicting as well as complementary interests and demands, deterrence-based policing dominates ideology and practice and is most likely to receive official attention in training and supervision.

The core task of a police organization in the criminal justice system is to procure arrests so that the system may control crime by deterring criminals through punishment. Police organizations are, however, rather loosely integrated around this core function. There are few achievement entrance requirements for officers, their training is modest, and supervision at work is limited. Middle managers search for matters to manage and the top echelon responds to the daily crises rather than to long-range planning needs. What is most apparent about police organizations, however, is how little attention is formally given to daily police practice, except when it involves a charge of misconduct. What is commonly assumed is commonly found: informal rules and practice dominate officer conduct both in decisions to arrest ${ }^{59}$ and in decisions about keeping the peace. ${ }^{60}$ When making decisions police are expected to exercise judgment on many, indeed most, matters without formal training or supervisory guidance.

Should one attempt to determine how the police come to exercise such enormous discretionary powers, it is all too easy to conclude that the answer lies in organizational mandate and history of the police. Without denying the merits of this claim, it is striking that anyone trying to tell the police how to practice police work or how to make choices would find that there is little information upon which to make such suggestions except what the police report says they do or what they are observed to be doing. Much of the reason for this state of affairs is that research has focused almost entirely on the decision to arrest, rather than upon a comparison of its efficacy with alter-

58. P. Scharf \& A. Binder, supra note 57, at 202-09, 222, 235-36; Reiss, supra note 57, at 130.

59. D. BlaCK, supra note 48, at 85-107; Black \& Reiss, supra note 12, at 68-75; Reiss, supra note 9.

60. P. Manning, Police Work 143-44 (1977); A. Reiss, supra note 6; van Maanen, Working the Street, supra note 30 . 
native ways of handling police matters. This suggests that one cannot structure police discretion and control its exercise very well because there is a lack of knowledge as to how to practice policing in a way that meets either compliance or deterrence objectives. No one has made the study of police problems and ways of coping with them the object of systematic inquiry that would allow the development of systems for choosing among different practices and for training officers in the exercise of choice.

Consider an area in which there is recent and important work on police practice: the spouse-assault experiment by Sherman and Berk in Minneapolis. ${ }^{61}$ The conclusion of that experiment may lead police administrators to a simple alternative, that arrest of the spouse has a specific deterrent effect when compared with other treatments, such as counseling or ordering the spouse from the house. Yet, those who conducted the experiment are well aware that, while arrest is a reasonably standardized intervention, the other choices, particularly counseling, are much less so. The police are not trained in any of the experimental interventions, and it is difficult for either the police or the experimenters to do much more than describe these forms of intervention in very general and highly discretionary terms. In the Minneapolis experiment, like most social experiments, it is easier to conclude that something works than that something does not. ${ }^{62}$ Moreover, the more difficult it is to operationalize any treatment and the more heterogeneity within a treatment, the less reliance one can place upon the conclusion that some treatment does not make a difference, or that it makes relatively more or less difference. It is conceivable that structured treatments other than arrest might be more effective in deterrence than arrest. To reach that conclusion, however, one must be able to define a practice and standardize it in order to control officer discretion in choosing among alternatives.

The spouse-assault experimenters can hardly be faulted for the fact that they are testing current police practice. The difficulty in evaluating alternatives to an arrest lies in part in knowing what is involved in current police practice. Even greater difficulty lies in the fact that so little is known about viable alternatives for dealing with spouse assault. Yet, there is a sense in which experiments in police practice come to be dominated by a deterrence rather than a compliance model. The issue addressed in these experiments is a determination of the effect that arrest has as a deterrent. The problem could just as easily be formulated to ask what kind of police practice, if any, might prevent spouse assault from occurring. Another matter that could be addressed is whether, given spouse assault, an officer must first diagnose the situation to determine which of a number of alternatives might be most effective. The latter question will require a rather different kind of experiment, one in which the population is stratified into types of spouse assault. Setting

61. Sherman \& Berk, supra note 50, at 261-72.

62. The problems of evaluation in criminal justice are summarized in ThE REHABILIATION OF Criminal Offenders: Problems and Prospects 54-87 (L. Sechrest, S. White \& E. Brown eds. 1979). 
aside the question of how one can learn about the effectiveness of different kinds of practice for different kinds of police problems so that practical choices may be structured, the fact remains that, in the absence of such systematic knowledge, one must base the development of training and practice upon the folklore of police practice in peacekeeping.

\section{Public Compliance and Officer Compliance}

The principle objective of police systems is to secure citizen conformity to the law. What is problematic is how to obtain public compliance. In the process of securing compliance, the behavior of the officer also may be problematic, since the officer's behavior may not be in compliance with the law. Police compliance often is at issue in police practice aimed at securing public compliance.

Deterrence-based systems focus their law enforcement strategies on controlling serious crime by arresting violators. The legality of the behavior of the officer in making an arrest and in securing evidence is at the core of officer compliance in deterrence-based systems.

A great many police matters, however, involve less serious crimes or "soft crime" such as drunkenness, littering and loitering, vandalism, or public safety. The police, moreover, may be expected to convince citizens that they need have little fear of victimization by crime. That fear may result from symbolic behavior exhibited by members of deviant populations, from the presence of businesses that attract outsiders unwanted by residents, or from the physical appearance of a community. ${ }^{63}$ Though arrest can be a strategy for controlling soft crime, there are alternatives. These alternatives often are based on coerced compliance-using the threat of arrest to coerce conformity in the future.

Techniques of securing compliance, nevertheless, can lie at the margin of professional police practice. An example of such techniques is what is called police harassment. Police practice that focuses over time on the same target populations or individuals to secure their compliance may well be regarded as harassment. Coerced compliance also invites practices of questionable legality. Nowhere are such practices more evident than in the control of loitering or disorderly conduct, conduct that often contributes to a fear of victimization by crime. Practical dilemmas are posed for the police because of demands arising from the transient population of business districts, especially that of central business districts and shopping areas in which the police control panhandlers, loitering youths, drinking in public, disorderly conduct, sleeping in doorways, littering in the streets, and speeding vehicles or blaring radios. The objections of persons in residential areas to the same conduct, as well as to drug-selling, prostitution, the behavior of clients of attractive nuisances located in their neighborhoods, and vandalism, likewise invite discretionary malpractice. Inasmuch as such violations are not easily controlled by

63. See Wilson \& Kelling, Broken Windows: The Police and Neighborhood Safety, ATL. MoNTHLY, Mar. 1982 , at 29. 
arrest and are unlikely to be taken seriously by criminal justice agents, police managers and police officers resort to peacekeeping techniques of control. ${ }^{64}$

There are different ways of controlling soft crime short of arrest. Many attempts to secure compliance by means alternative to an arrest, however, run the risk of being considered improper, if not illegal. Consider, for example, controlling the behavior of loitering youth who induce fear of purse snatching among women shoppers or of assault to older people and others who must pass such a group. Control of the congregation of males who make lewd references that offend women passers-by is similarly problematic. Much of this behavior may never quite pass the threshold of arrest that will survive a charging process, much less punishment by the criminal courts. Yet, residents, business people, and daytime populations of buyers and workers wish to be free of the threats posed by congregating and loitering. The legal restraints on the police for controlling such behavior loom large, given the rights of citizens in public places. Continued police presence, requests to move, questioning, and repeated arrests for minor offenses such as littering or spitting on the sidewalk are understandable responses, if not altogether acceptable practice. What is at issue, however, is whether there are legally effective ways to secure compliance so that the threats of congregation are minimized.

One might pose a number of alternative practices to those that lie at the margin of acceptable or legal practice, but little is known about whether, how, and under what conditions such practices work. Moreover, far less is known about how to secure compliance by incentive rather than by coercion.

The overlap between policing soft and serious crime poses additional issues of determining officer compliance since the policing of soft crime can be a subterfuge to circumvent legal rules. Traffic stops become a basis for observation, interrogation, and vehicle search. Arrest on technical violations, such as failure to have an automobile registration in one's possession, may provide additional opportunities for warrant or other checks or inquiries. Drunkenness charges may be used to control loitering and summonses for blocking traffic to control prostitution. Citations for ordinance violations become not only a means of controlling behavior in public places but of controlling soft and hard crime when it is not amenable to legal control by line officers.

The dilemmas and contradictions in officer compliance that arise in the course of police efforts to secure civic compliance lead one to question whether the matters of officer compliance and citizen compliance can be treated independently. Deterrence-based models do treat these matters independently. The core problems of officer compliance, however, are problems of legitimate police practices to secure conformity. Absent appropriate ways for the police to secure compliance when deterrence models fail or are inappropriate, discretionary malpractice as well as routine practice is limited.

64. Bitner, supra note 23, at 714-15. 
Studies of professional malpractice suggest that it is much easier to control malpractice if there are prescribed methods of practice and if discretion is constrained by legitimate ways of reaching objectives. The failure to provide the police with means other than arrest and their wits may lie at the core of the misuse of discretion.

\section{VII}

\section{Control of Police Discretion through Organizational Ghange}

\section{A. Control by Administrative and Criminal Law}

Compliance-based systems of law rest in administrative law and procedure, whereas deterrence-based systems lie more firmly within the domain of criminal law and procedure. Administrative law has developed largely with the increasing federal regulation of organizational behavior that is harmful or inimical to public interests. ${ }^{65}$ It mainly concerns agency behavior, not the maintenance of a criminal justice system. Indeed, it has become apparent "that judicial review alone, or even in combination with legislative oversight, is inadequate to discipline administrative discretion." 66 The same conclusion can be reached with respect to attempts to constrain discretion by criminal law and procedure. The problems lie in the nature of the review and who is responsible for it. ${ }^{67}$ To review, one must allow behavior, including violations of law by practitioners, to occur. Review is therefore postmonitory-after the fact. It becomes increasingly clear, however, especially in administrative law, that if organizational behavior is to be controlled, it must be affected prospectively through premonitory control.

Premonitory control lies at the heart of controlling the behavior of organizations and their agents, whether that of a police department and its police officers or a private corporation and its employees. The control of police discretion and misconduct, for example, appears to require mixed strategies in which both premonitory and postmonitory control are exercised. To control police corruption, premonitory controls may be more effective than postmonitory controls. ${ }^{68}$ Legalistic requirements and review followed by punishment, especially punishment of the organization, tend to inhibit managerial discretion, impair its effectiveness, and make it less responsive to external demands for change. ${ }^{69}$

65. Administrative law, though, has long existed as part of legislation that creates excutive agencies, public boards, and commissions.

66. Payton, Administrative Law: What Is It, and What Is It Doing in Our Law School?, LAw Quadrangle Notes, Fall 1983, at 29, 30.

67. Williams, supra note 53 , at 436-37.

68. A. Reiss, supra note 6; L. Sherman, Scandal and Reform: Controlling Police CorrupTION 55-56, 165-66 (1978); Reiss Foreword to L. Sherman, supra, at xiii (1978).

69. Payton, supra note 66 , at 31 , concludes that the central problem in administrative law is how the development of procedural and organizational reforms of public participation, disclosure of 
In comparing organizational behavior under administrative and criminal law, it is apparent that a strategy of postmonitory control predominates in criminal law agencies more than it does in administrative law agencies. Often, what is permitted under administrative law is circumscribed under the criminal law. As has already been noted, administrative law may grant considerable sanctioning power to agents and may enhance their capacity to coerce compliance since the object is to regulate rather than punish conduct.

Of the organizations responsible for formally controlling the behavior of people and their organizations, police organizations are perhaps most likely to act within the double bind of administrative regulation and criminal sanctions. It was observed above that policing originally coalesced regulatory with common crime control functions. The object of combining these functions was more to secure compliance and to maintain public order than to control crime. It was concluded that, although police departments today are formally in the business of crime control, they are also very much in the business of regulating and controlling conduct. Consequently, police organizations are a mix of law enforcement functions. They are both a regulatory agency and a criminal justice agency; they seek both compliance and deterrence. ${ }^{70}$ This mix of functions is volatile for police administrators and police employees and is not easily handled by them absent formal organization and procedures for carrying out both mandates.

Policing operates through territorially organized law enforcement agencies. Neither the problems for legal regulation nor the occurrence of crime, however, are uniformly distributed within a territory. Although the police are well aware that the volume of criminal activity varies among neighborhoods, within cities, and across communities, ${ }^{71}$ they are less likely to be aware of how problems of keeping the peace, maintaining public order, and insuring compliance with the law vary among geographic territories, except perhaps for traffic control. The local, state, and federal regulatory and enforcement agencies, except for fire departments, are even less likely to observe territorial variations. In any case, the two kinds of information are rarely mapped together to provide a comprehensive profile of the problems of enforcing the law when it is divided among diverse agencies. The residents and organizations located within any territory, however, are well aware of the consequences of law viola-

information, and adversary challenge interferes with managerial discretion and the capacity of the organization to execute its mandate.

70. Administrative agencies likewise are charged with responsibilities in accordance with adminstrative and criminal law requirements. Some agencies even have powers of arrest as well as powers to exact compliance without arrest. As a result, administrative agencies encounter dilemmas similar to those encountered by police organizations. The IRS, for example, makes discretionary choices about when to proceed with criminal indictment, usually choosing to negotiate compliance. In doing so, it recognizes that the legalistic requirements of a criminal proceeding pose considerable problems for its ordinary investigation techniques and compliance enforcement. For a discussion of problems of prior investigation and its relationship to criminal proceedings on tax matters, see $\mathbf{S}$. Long, The Internal Revenue Service: Measuring Tax Offenses and Enforcement Response $435,157,177$ (1980).

71. Reiss, How Serious is Serious Crime?, 35 VAND. L. Rev. 541, 580-83 (1982); Wilson \& Kelling, supra note 63 , at $30,32,33$. 
tion for their way of life and may have a better sense of the diversity of control to which they are subjected than do the agencies themselves. The administrative separation of control in territories has costs and consequences for both controllers and controlled. The major consequence of the territorial concentration of law violations is its effect on the quality of life: crime is not only symbolically represented in communities but it affects the quality of collective life. ${ }^{72}$ The deterrence approach to law enforcement concentrates on individual victims and violators rather than on communities. A territorial, neighborhood, or community approach to crime control, on the other hand, is concerned with the consequences that violations of the law have for those territories.

Although a deterrence-based model of arrest may have some favorable consequences for the quality of life in communities, for many communities a far more massive approach to law violation seems essential if one is to affect the consequences of law violation in any meaningful way. One need only visit many high-crime-rate communities to observe that the consequences of violating the laws for which regulatory agencies are responsible are more in evidence than are the victims of serious crime. Moreover, there is far greater visibility of the consequences of what are regarded as less serious and soft crimes than of serious crimes. The consequences of vandalism, fire-damaged buildings, prostitution, drunkenness, littering, and loitering are visible everywhere in high-crime-rate communities. Indeed, the failure to enforce the law for these offenses appears to launch community careers in crime that eventuate in high serious-crime rates. ${ }^{73}$

The problem for many of these communities is that managerial discretion to enforce the law does not focus on communities. Agent enforcement, moreover, is not coordinated and the exercise of discretion may only exacerbate the problem of control. The division of responsibility among regulatory and justice agencies and the lack of cooperation among them contribute to the failure of discretionary enforcement for communities. To interface deterrentand compliance-based objectives of law enforcement within and among law enforcement agencies will require considerable redesigning of agency structures and their mandates.

\section{B. Increasing Police Powers to Regulate Conduct}

The legalistic control of police behavior inherent in the adversary justice model seems overly restrictive for a model of policing that seeks both to keep the peace and to secure compliance with the law. Where both peacekeeping and compliance tasks are given to the same agents, problems arise-not only problems of how to exercise discretion in situations, but also problems of how legalistic constraints on the justice role have consequences for the compliance role.

72. See Wilson \& Kelling, supra note 63; Reiss, Crime Control and the Quality of Life, 27 AM. BEHAvIORAL Scientist 43, 54-59 (1983).

73. Reiss, supra note 71 , at $575-85$. 
One might argue that this dual role problem can be resolved by assigning tasks to different agents in the same organization, ${ }^{74}$ a solution analagous to the separation of regulation from justice goals in separate organizations. The internal separation appears unrealistic, however, given the situational nature of much discretionary enforcement in public policing. Simple separation by task and agent is problematic when there is such a great diversity of individual and organizational conduct to be controlled.

There is no simple answer to the question of whether or not police powers should be changed to accomodate the dual roles of police officers as regulatory and justice agents. It seems worthwhile, however, to undertake an exploration of ways in which these dual roles and objectives can be accomodated. Whether and in what way police powers must be changed will rest upon how one devises those accommodations. It is shown below by several examples how some formal deterrence and informal compliance actions can be treated more explicitly as compliance matters in public policing.

\section{VIII}

\section{Towards a Mixed Model of Public Policing}

Although line police officers use compliance strategies and tactics in policing everyday life, police organizations and legislative bodies ordinarily do not give formal recognition to the use of compliance strategies. Compliance strategies are usually provided by legislatures for separate bodies who employ their own cadres of law enforcement agents. This practice often leads to considerable variation in the ways in which laws are enforced. The consequences of violent use of handguns, for example, may be met with a tangled web of regulatory control and criminal law enforcement. Several examples of how matters that have been or might be formalized as compliance actions in public policing are given below to illustrate both how deterrence-based police matters can be treated within a compliance model and how the public police might share in compliance- as well as deterrence-based law enforcement.

\section{A. Enforcement of Vehicle Safety and Emission Standards}

The setting and enforcement of vehicle safety and pollution standards lie in a tangled network of federal, state, and local regulatory and law-enforcement agencies. Which of these agencies has responsibility for setting standards and for selecting strategies and tactics of enforcement depends, to some extent, upon the nature of the standards to be enforced and the number of cases that an agency or agent must deal with in daily work.

The more that compliance standards can be determined by technical or scientific considerations, the less likely standards are to be negotiable. When

74. This dilemma often is resolved within regulatory agencies by shifting responsibility for continuing investigation from one investigation division to another and from one class of agents to another. The IRS moves the case from civil to criminal investigation, for example. See S. Lonc, supra note 70 , at 22 . 
negotiation occurs, it is more likely to be with respect to nontechnical matters, such as the timing of compliance. Negotiation standards, moreover, are more likely to be opted for when there are relatively few organizational units to be controlled, their identity is known to controllers, and a continuing relationship between controller and controlled is organizationally feasible. All of these conditions prevailed in the setting, promulgation, and enforcement of mandatory fuel economy standards by the National Highway Traffic Safety Administration for passenger and nonpassenger automobiles produced in or after 1978.75 Although there was some negotiation with the domestic automobile manufacturers over the threshold of emission standards, major negotiation and renegotiations have occurred with respect to the timing of compliance, linking threshold to model year compliance. Enforcement, moreover, meets the conditions of small numbers and continuing relationships, making compliance enforcement largely a matter of inspections testing for compliance with technical standards, matters that can, in fact, be settled prior to assembly-line manufacture.

When the number of units to be controlled is large, compliance strategies and tactics are generally nonnegotiable. Each manufactured automobile is potentially noncompliant. Hence, the states have sought to enforce emission standards for each operating licensed motor vehicle. The number of such vehicles is far too large to admit of anything other than a formally structured system of inspection where owners are held responsible for meeting an emission standard. The system allows almost no leeway for negotiation with individual motor vehicle owners over noncompliance. Noncompliance is met with a standard period for bringing the vehicle into compliance and a date set for reinspection.

The system of inspecting each motor vehicle depends upon each individual presenting his motor vehicle for inspection. Individual owners, however, may fail to do so or fail to bring a vehicle that does not pass inspection into compliance. The responsibility for addressing noncompliance falls to the public police, who issue summonses for such failures. At this point, systems vary considerably as to whether and how the police are involved in a compliance- or deterrence-based strategy. Where the object is to achieve compliance with emission standards rather than to punish for noncompliance, the owner can escape the penalty if proof of compliance is brought to law enforcement authorities. Where the object is punishment, compliance is unnecessary if and when the penalty is met. Indeed, unless fines are sufficient to exact compliance, owners may continue to risk noncompliance. It seems quite obvious that the more the public police are involved in a compliance strategy for emissions compliance of motor vehicles, the more likely the system is to achieve the objective of the enforcement without the necessity of invoking deterrence costs. A coerced compliance strategy for the public police, then, is probably the more effective in vehicle compliance. 


\section{B. Handgun Control}

Gun control in the United States is a patchwork of federal, state, and even local gun laws. These laws vary considerably as to whether and how control is to take place, who is to be controlled, and what is to be controlled. Some strategies are aimed at manufacturers and dealers, such as laws requiring licensing for sales. Other strategies are aimed at control of purchasing, such as laws requiring permits to buy or registration of ownership. These are primarily based on coerced-compliance strategies. Other laws prohibit ownership of all guns, prohibit the carrying of guns in public except by exempt persons, or ban the possession of specific types of weapons. The enforcement of these laws is commonly given to the public police and is based upon a deterrence-based strategy of enforcement-arrest for violation of these laws. Another class of laws, however, is aimed at deterring offenders by increasing the penalties for weapons-related offenses, such as the use of a handgun to commit a felony. Officers are expected to charge that specific offense on arrest.

Just how effective police officer strategies are in deterring the use of handguns to commit crimes is unknown. What does seem clear is that most persons who commit crimes using handguns were not detected as possessing or carrying a handgun in a public place prior to commission of such crimes. Given the difficulties in detecting offenses such as carrying and possessing concealed weapons and restrictions on body and vehicle searches under the criminal law, it seems reasonable to conclude that there are many violations of these gun laws that go undetected.

What may seem surprising is that a far more effective strategy of handgun and weapons detection is carried out in everyday life with metal detector searches at airports, where the inspection of persons and property passes as a voluntary compliance strategy. Quite possibly, such screening might be extended considerably to control the carrying of deadly weapons in public places. Consider, for example, the installation of screening devices at the entrance to subway stops or public schools where weapons offenses are common. Consider also the possiblity of equipping our public police with metal detectors and permitting detection screening in public places. One need not, moreover, treat all detected violations as requiring an arrest. Forms of confiscation and repossession of property should be permitted under limited circumstances. What is at stake here is whether the behavior of the police must be governed entirely by a criminal law model of deterrence and arrest or whether their behavior can be judged also in terms of a model of compliance inspection with automatic penalties for noncompliance.

\section{Soliciting: Pandering and Prostitution}

The history of prostitution in the United States can be described as a movement from the disorderly house of business operated by a madam to street importuning controlled by male pimps. Behind that shift is a history of changing law enforcement. 
The bawdy or disorderly house of ill-repute operated by a madam was the result of a mixed strategy of policing whereby coerced compliance dominated over deterrence policing, which was used only to restrict the form and place of practicing prostitution. For much of the nineteenth and early twentieth centuries, police confined prostitution to "red-light districts" or secluded locations, arresting only those who failed to practice under these conditions. Harassment was more likely to be used than arrest as a means of confining practice to organized businesses. Prostitution found a niche in urban towns and rural communities. With its protected status, it developed an oligopolistic market that effectively eliminated competition from street prostitution. The market control of competition ordinarily was sufficient to eliminate the necessity for deterrence policing to restrict the practice to particular businesses and locations.

Given the illegal status of prostitution, the coerced compliance strategy of law enforcement was informal and open to corruption. Moreover, the illegal status of prostitutes made them vulnerable to moral entrepreneurs who would enforce a moral order on early twentieth-century America. Abetted by a public-health movement to control the spread of venereal disease, disorderly houses were driven from business by arrest and harassment of their operator madams. Prostitution was dispersed to the public streets and byways. The pimp, the john, and the whore emerged as a triad to respectively extort, cruise, and solicit in an organized extortion racket. When confronted with this new form of business, the police adopted a mixed strategy to control prostitution, in which deterrence policing dominated and coerced compliance in the form of harassment was used as an auxiliary tactic. Prostitution became class-differentiated, with call girls and bar solicitation serving the more affluent and street trade serving the casual customer and the less affluent. Only street trade became a major focus of police control since the former was dominated by private market strategies. Street prostitution was controlled by harassment and threats of arrest; prostitutes became vulnerable to police drives to maintain a semblance of moral order and were driven to pay both pimps and the police to operate.

Driving prostitution to the streets added a new dimension to the practice of prostitution. Male pimps who coerced prostitutes into forced labor replaced the employing madam. Prostitutes were subject to extortion and assault by pimps. Added also was a coerced relationship between pimp and prostitute that victimized clients, exposing them to pimping crimes of theft and assault. The dispersed model of prostitution and its policing increased the kind and amount of crime that was prostitution-related. In recent years, prostitution has become part of a network of street trade in drugs.

Clearly, the model in which a strategy of deterrence policing dominates appears relatively ineffective as a means of controlling prostitution. As compared with the coerced compliance model and its illegal house of prostitution, it generates more violent crime, inducing coercion of prostitutes by pimps and sporadic robbery and assault of clients. 
Perhaps the major drawback of the disorderly house, coerced-compliance approach to controlling prostitution is its vulnerability due to its illegal status. Prostitution in some countries, such as the Netherlands, is a regulated business, subject to licensing, and with restricted locations for practice. Evidence from the legalization of prostitution in the Netherlands discloses that ordinary foot patrol by the Amsterdam police is effective in controlling crimes associated with the practice of prostitution in the area. ${ }^{76}$ Prostitution played no role in the recent corruption scandal involving the Amsterdam police. ${ }^{77}$ Licensing, moreover, can also be used control the spread of veneral disease when a regular medical examination is a condition of continuing license to practice. This coerced-compliance model, of course, carries with it the threat of coercion by arrest for unlicensed prostitution and revocation of licenses for failure to conform to the requirements of licensed practice. For the most part, however, the combination of regulated legal prostitution and a segregated market where negotiation over price is possible limits the amount of crime associated with prostitution and simplifies police control of its practice.

There appears to be the possibility that simple decriminalization may resolve the prostitution problem. There are some drawbacks in complete deregulation of prostitution, however. In particular, prostitution becomes possible at any location and under a broad range of conditions, subject only to the control of citizen behavior in public places. Moreover, it remains vulnerable to extortion from pimps who set out to control market locations. The police then are faced with community pressures to control legal conduct, which may be illegally practiced and open to extortion. Soliciting without consent and control of pimping become problematic areas of enforcement for the police. From the perspective of policing, a regulated business under coerced compliance seems the more viable strategy for controlling prostitution.

This example of prostitution as a regulated business may serve to illustrate how the organization of an activity and its regulation facilitates its control without resort to enforcing the law by arrest. The legalization of heroin sales to addicts through licensed pharmacists is another example of a compliance strategy in law enforcment. Perhaps the more one can legalize and regulate activity that is associated with soft crime in a compliance mode, the more one can effectively control it, since the relationship between controllers and controlled is stabilized when exchanges are structured between organizations rather than between individual entrepreneurs and members of a police organization.

\section{Juvenile Loitering}

A growing concern of both resident and daily transient populations is the fear of victimization by crime as they move to and from work or about their

76. M. Punch, Policing the Inner City 144-47 (1979).

77. See Punch, Developing Scandal: Police Deviance in Amsterdam, 11 URB. Life 209 (1982). 
neighborhoods. Loiterers are especially threatening. Such relatively stationary and publicly visible loitering groups and individuals often increase the sense of fear engendered by harassment. For a variety of reasons, such offenses are at the margins of the criminal law and unlikely to be regarded as serious matters in either the juvenile or the adult criminal justice systems. A deterrence strategy relying on arrest is ineffective for the most part and requires considerable manpower where recidivism is high.

There is no single compliance strategy for dealing with the various forms of loitering and its associated offenses. For juveniles, there often are additional and associated status offenses, such as truancy and curfew violations. Recently, however, a number of police departments, such as those in Newark, New Jersey, and Oakland, California, have begun to develop coerced compliance strategies for coping with juvenile loitering and some of its associated offenses. The loitering that takes place during school hours is normally associated with truancy. The tactic under those conditions has been to coerce compliance with school-attendance laws rather than to attempt to deter loitering. A simple model of coerced compliance, followed in Oakland, California, is to approach all youth who appear to be of school age and determine whether there is reason to conclude that they are truant. If there is reason to believe that a youth is truant, he or she is taken to a Board of Education Center where it is determined whether or not the youth should be in school at that time. Youths who are truant are transported to the school and monitored for attendance. Although there is some absconding and a pattern of truant recidivism, a reasonable reduction in truant rates occurs with this strategy. Moreover, the strategy discourages truants from congregating, lest their loitering behavior attract attention.

Here again is an example of how a coerced-compliance strategy seems more effective than a deterrence-based one in controlling behavior. Indeed, this is an example in which compliance with school attendance laws is achieved in a short period of time and both crime associated with truancy and the public fear of victimization associated with loitering behavior are reduced.

\section{E. Crimes Associated with Drunkenness}

There are a variety of offenses associated with drinking behavior, including, in some places, public drunkenness and, in most places, the attendant crimes of disorderly conduct or operating a motor vehicle while intoxicated. For the most part, deterrence modes of policing and treatments associated with arrest and processing in a criminal justice system appear ineffective in controlling offenses associated with intoxication. ${ }^{78}$ Without directly dealing with the problem of reducing drunkenness, compliance modes of policing its associated conduct are possible, as recent strategies of control illustrate. The transportation of public drunks by the police to detoxification

78. Holden, Rehabilitative Sanctions for Drunk Driving: An Experimental Evaluation, 20 J. RESEARCH Crime \& Deling. 55 (1983). 
centers, for example, serves not only to control their behavior in public, but also often protects the intoxicated person from victimization by crime or from personal danger arising from an intoxicated state. There are also alternatives to arrest for operating a motor vehicle while intoxicated. These alternatives include civil suits for damages arising from drunkenness against bartenders who served the intoxicated person, and paying closer attention to whether bar operators are complying with the law regarding the serving of liquor to intoxicated persons. Civil suits and license revocation for violation may be more effective than arrest of intoxicated persons.

Still other modes of coerced compliance are possible, such as patrolling bars that regularly serve intoxicated persons at late hours. Persons appearing to leave intoxicated who begin to drive may be required to take a sobriety test. Failing the test might lead to transportation of the intoxicated person to his or her residence or to a detoxification center as well as impounding of the automobile. The cost of impoundment and a graduated set of penalties for recovery of the vehicle associated with repeat offending may be far more effective than simple arrest and incarceration of the offender pending a court appearance. ${ }^{79}$ In the latter instance, there is a mixed compliance and deterrence model. The offending or intoxicated person is not subject to arrest and in fact is transported for his or her safety. The deterrence effect arises through two kinds of associated costs for recovery of the motor vehicle-the time and cost taken to recover the automobile and the fine that must be paid prior to its recovery. Such mixed strategies of compliance and deterrence are possible where one permits a more diversified model of policing that is not associated simply with penalties under the criminal law, and where police officers are given responsibility for enforcing administrative as well as criminal law matters. ${ }^{80}$

\section{F. Problems on the Way to Achieving Mixed Model Policing}

When one introduces compliance models into a policing scheme that is dominated by the criminal law, one risks the attack of such models on legalistic grounds of the criminal law, for our public police are held accountable largely under the criminal law and criminal procedure applicable to the conduct of its agents. Careful historical examination discloses legitimated police practices no longer used because they fell to the legalistic control of police conduct. The posting of premises as raided to serve notice of police control of illegal activity has disappeared under legal challenge in New York City. The peace bond used by the Detroit police to control domestic violence is

79. Penalties may be in the form of instant justice if there is evidence of prior penalty. The equivalent of a day-fine might be instituted or the penalty might be linked to the value of the motor vehicle.

80. Note that the sanctions of license revocation and fines are as common to administrative as to criminal law. What is at issue is whether imposing such sanctions should be grounded in criminal or administrative law, whether a police officer should enforce administrative as well as criminal law matters, and whether police agencies should be formally granted powers other than those of enforcing the law by arrest. 
under challenge. So long as policing is dominated by a deterrence-based justice system, compliance strategies will be judged in terms of legality under the criminal law.

There are, of course, no simple ways to formally merge formal compliance- and deterrence-based law enforcment within the same formal organization. One the whole, American law enforcement has opted for the separation of such models. Still, a large number of tax and other law enforcement agencies merge criminal with compliance investigations so that there are models that can be followed. What does seem clear is that unless one begins to formally recognize these models of controlling behavior, it will be difficult to hold police accountable for their exercise of discretion.

\section{IX}

\section{What Is Legal Police Conduct and What Works in Controlling LaW Violations?}

This article has posed some dilemmas that arise when workers are placed in the position of controlling the behavior of others but their means of control are open to challenge by those controlled. The problem is an especially troublesome one because at its core may lie the conclusion that what works well cannot be permitted under the law. Behind that conclusion lie choices among values where there are no simple rules to govern those choices.

Within the behavioral sciences there is a growing cadre of scientists who try to determine how effective a course of action is in reaching a given objective. They have turned their attention to evaluating different police practices and means of legal regulation. Though their power to provide answers is limited by the state of their science, they too find that their conduct is constrained by law and by their capacity to alter conditions to examine their effects. Police managers face similar dilemmas as they seek to determine what are effective modes of policing different populations in accordance with concerns about controlling crime and performing traditional peacekeeping functions while reducing the fear of crime and meeting the demands of diverse interest groups for compliance with the law.

In trying to find out what works, one must face the problem of whether and in what ways one must take into account the legality of police practices in determining the effectiveness of such practices. To what extent will the law and its application be constrained by the fact that something works? An illustration of this kind of dilemma is found in gun control legislation and experiments in the control of handguns. Some gun control legislation and experiments raise issues about whether they would survive constitutional challenge given the limits imposed by the fourth amendment, as applied to the states through the fourteenth amendment.

One of the most controversial legal issues surrounding gun control experiments is whether one can randomly stop citizens to search for weapons. A more limited strategy, the so-called "non-stop" stop and questioning as a tactic for enforcing gun laws, seems less controversial. Whether or not metal 
detectors can be used in public places to search for weapons is a grey area under the law. Clearly, metal detectors are used under many circumstances in which there is conditional consent, whether to enter a prison, board an airplane, or enter the White House as a visitor. Their use in the street without prior consent is another matter, however. There seems little doubt that metal detectors carried by police officers might be effective in detecting the illegal carrying of handguns, but the issue of their effectiveness does not stop there. As Mark Moore has argued, much also depends upon whether the way in which one responds to the dectection of handguns has an effect on their use in crimes against persons. ${ }^{81}$ Should one arrest an individual for illegal carrying to deter illegal gun-carrying, return the gun when there is a reasonable presumption that it is for self-defense, or simply confiscate the gun? In order to determine the effect of each of these courses of action, one must conduct experiments on the use of metal detectors to detect illegal carrying, on the variation of responses to discovery, and on the impact of these different responses on some behavior, such as the use of guns in violent crime or rates of illegal carrying. It would hardly seem worthwhile to undertake such experiments unless there were reasonable presumptions that the police practice, if effective, would survive legal challenges. Yet, the chances of surviving legal challenges may well be enhanced by the positive results of experiments.

Persons trained in the law are quick to point out that there are substantial differences in the degree to which persons are aware of and consent to ferromagnetic or other technological searches. Yet, the differences are less clear if one recognizes that many such searches are a matter of coerced compliance. If one has to fly airplanes to hold one's job, one is hardly all that free to resist a search for weapons. One may indeed be prohibited from personally carrying onto an aircraft any object that is defined as dangerous by the inspectors. Much compliance, then, is coerced and regarded as perfectly acceptable under some conditions but not others. The rationality of such differentiations within the law is not always easily fathomed. One certainly appears more at risk of being killed by handguns carried on the streets, where stops for detection might be prohibited, than by handguns on planes, where weapons are prohibited.

To a growing extent, police practice may be placed under the scrutiny of evaluation by experiments or other forms of research evaluation. Social science theory and models may increasingly guide the testing and development of practice as police come under the control of the management sciences. There is much greater opportunity for research and experimentation where there are fewer legal barriers to the practice. The IRS Taxpayer Compliance Measurement Program, for example, is highly intrusive of the privacy of individuals, yet readily legitimated as a technique for determining compliance with the IRS's filing and reporting requirements. ${ }^{82}$ This example may suggest that there would be far more opportunity for determining effective means for

81. Moore, The Police and Weapons Offense, 452 Annals 22, 23-27 (1980).

82. S. LoNG, supra note 70 , at 53. 
policing a population and implementing these means were one to shift more matters away from criminal justice sytems to regulatory control. Perhaps handgun ownership and possession should be regulated and not treated as criminal matters, except in situtations in which guns are used in felonies. There already are some shifts in that direction in regulating sale and ownership of handguns. What is suggested, then, is that there is a need to consider how matters can be shifted to legal regulation rather than how to make the criminalization of conduct more effective, since, at least for the time being, there are fewer constraints for finding out what works under the former conditions.

\section{$\mathrm{X}$ \\ SUMMARY AND CONCLUSIONS}

Within the criminal justice system, police discretion is molded within a deterrence rather than a compliance model of controlling behavior. Police managers generally opt for a crime control model that is deterrence-based. Yet, control by the law of arrest is hardly germane to much of police business, even that which falls clearly under the domain of the criminal law. Line police officers often are concerned with the business of negotiating compliance or enforcing compliance with the law and custom without having to punish or restrain by arrest. They come to consider different ways of handling matters that are brought to their attention, abandoning the restrictions posed by the law of arrest. In many situations, they are not simply content to take any action short of an arrest because they know that the problem often will not go away. Line police officers, therefore, consider other ways of dealing with a situation that they regard as troublesome, refusing to treat it simply as a matter of law violation. Consequently, they often choose a compliance rather than a deterrence option.

An emphasis on punishment and justice in the criminal justice system leads police managers to emphasize a deterrence-based model of policing in which clearance of crimes known to the police by arrest dominates. This deterrence-based policing likewise leads to an emphasis on controlling violent crimes against the person and crimes involving substantial dollar losses against property. Lesser crimes that may be quite serious in their consequences for individual and collective life, such as vandalism and soft crimes such as prostitution, littering, and loitering, are given less attention. The line police officer often practically has responsibility for controlling crime, maintaining public order, and otherwise keeping the peace.

The emphasis on the deterrence-based model of policing, coupled with a disenchantment with the concept of a preventive patrol, often leads police managers to a reactive mobilization model in which police are deployed in cars and their contact with citizens and neighborhood problems minimized. Proactive policing is generally given to special task forces or units which focus on particular problems rather than upon policing a community. The compli- 
ance model that underlies peacekeeping by a constabulary becomes dormant except in the informal practices of line officers responding to calls for service.

There are signs of a return to an older model of police patrol with its balance of deterrence- and compliance-based methods of policing. This model emphasizes the preventive functions of a more visible police, such as in mounted and foot patrol, and the compliance strategies and tactics of foot patrol. Likewise, concern about addressing the fear of crime and its consequences has led to a focus on neighborhood and community policing.

Policing may be entering a period in which managers are open to considering different ways of coping with law violation and its collective consequences for neighborhoods and communities of different kinds. Some managers have opened their departments to experiments and evaluation of police practice. These experiments and evaluations, however, seem dominated by a deterrence- rather than a compliance-based model of policing. What seems needed is greater attention to the role that compliance models, which are central to the strategy of regulatory agencies, can contribute to discretionary choices by police managers and their officers. An area that needs to be explored is how mixed models of deterrence and compliance, especially of coerced compliance, are more appropriate for the policing of communities.

Finally, the criminal justice system poses greater problems of the legality of enforcement actions for its agents than do regulatory agencies. There is some reason to reconsider the consequences of this emphasis on legality for both deterrence and compliance objectives of law enforcement. 